\title{
FLORA LEÑOSA DE LA PROVINCIA DE SANTA FE (ARGENTINA), RECONOCIMIENTO POR SUS CARACTERES VEGETATIVOS
}

\author{
Pensiero, J. F.1
}

\begin{abstract}
RESUMEN
Se presenta una clave dicotómica que permite el reconocimiento de 144 taxones de la flora leñosa de la provincia de Santa Fe a través de sus caracteres vegetativos. Para cada taxón tratado se incluye su familia botánica, nombre vernáculo más común, hábito de crecimiento, estatus geográfico, los departamentos de la provincia donde ha sido colectado y un ejemplar de referencia.
\end{abstract}

Palabras clave: Flora leñosa, Santa Fe, Identificación vegetativa.

\begin{abstract}
Woody flora of Santa Fe province (Argentina), recognition for its vegetative characters.

A dichotomous key is presented that allows the recognition of 144 taxa of woody flora of Santa Fe province through its vegetative characters. For each taxon treated, includes botanical family, the most common vernacular name, growth habit, geographic status, the departments of the province where it has been collected and a reference specimen.
\end{abstract}

Key words: Woody flora, Santa Fe, vegetative identification.

1.- ICIAGRO Litoral, UNL-CONICET-FCA. Kreder 2805. 3080HOF, Esperanza, Santa Fe, Argentina. Email: jfpensi@fca.unl.edu.ar

Manuscrito recibido el 14 de abril de 2020 y aceptado para su publicación el 24 de agosto de 2020.

Pensiero, J. F. Flora leñosa de la provincia de Santa Fe (Argentina), reconocimiento por sus caracteres vegetativos. FAVE - Ciencias Agrarias 20 (1): 55-81. CC BY-NC-SA 4.0 


\section{INTRODUCCIÓN}

La expansión de la frontera agrícola ocurrida en los últimos 50 años, particularmente a partir de 1996 cuando ingresaron a Argentina las variedades de soja Raundup Ready (RR), fue la causa principal de la drástica pérdida de importantes superficies de bosques nativos (Altieri y Pengue, 2006). Desde 1937 (año en el que se realizó el primer Censo Nacional Agropecuario) a 1987, se deforestaron en Argentina 4.344.866 ha de bosques nativos; durante el período 1998-2002 se continuó con dicho proceso a razón de unas 200.000 ha/año (Montenegro et al., 2004). En 2006 quedaban en Argentina 29.069.185 ha de bosques nativos (Paruelo et al., 2004; Grau et al., 2005; SAyDS-UMSEF, 2007; Aizen et al., 2009; Gasparri et al., 2013).

El territorio correspondiente a la región del Parque Chaqueño argentino comprende la totalidad de las provincias de Formosa, Chaco y Santiago del Estero; norte de Santa Fe y San Luis; este de Salta, Jujuy, Tucumán, Catamarca, San Juan y La Rioja, y noroeste de Córdoba y Corrientes. Dicho territorio conserva el $69 \%$ de los bosques nativos de la Argentina, y constituye la masa forestal más importante de maderas duras, y es una de las mayores en riqueza biológica luego de las Yungas y la Selva paranaense (SAyDS, 2005). Este territorio fue el más afectado por la pérdida de bosques nativos, pasando de una tasa de deforestación de -0,89\% (período 19982002) a -1,44\% (período 2002-2006), con un área deforestada de 1.223.891 ha (SAyDS-UMSEF, 2007). Además de la deforestación, estos bosques fueron afectados por una importante explotación forestal a través de la extracción de sus árboles más robustos y los de mejor calidad de made- ra (erosión genética) y, en consecuencia, la pérdida de biomasa (menor producción), dando como resultado bosques empobrecidos y comprometiendo seriamente sus posibilidades de aportar servicios ambientales (Montenegro et al., 2004; Luna, 2018). Un claro ejemplo de esto ha sido lo ocurrido en el norte de la provincia de Santa Fe con la explotación del "quebracho colorado chaqueño” (Schinopsis balansae Engl.), una de las especies forestales más valiosas del Parque Chaqueño (Gori, 1965).

En este contexto, en el año 2007 se sanciona la Ley Nacional No 26.331 "De Presupuestos Mínimos de Protección Ambiental de los Bosques Nativos”. En dicha Ley se establecen los presupuestos mínimos de protección ambiental para el enriquecimiento, restauración, conservación, aprovechamiento y manejo sostenible de los bosques nativos y de los servicios ambientales que éstos brindan a la sociedad. Para acceder a los beneficios que otorga esta ley se debe presentar un plan de manejo basado en el inventario de sus recursos y en particular, en forma detallada, de las especies leñosas que se proyectan explotar. En relación con esto, a la hora de realizar los inventarios florísticos y forestales, muchos técnicos (Ingenieros Agrónomos y Forestales) hallan complicaciones para el reconocimiento de las especies, ya que la mayoría de ellas pueden carecer de flores y/o frutos al momento de hacerlos, imposibilitando la identificación taxonómica tradicional. Tal dificultad se puede subsanar empleando a tal fin los caracteres vegetativos, presentando la ventaja en encontrarse durante períodos de tiempo prolongados y observarse con mayor facilidad.

La mayor parte de los trabajos que incluyen claves para el reconocimiento de especies leñosas a través de sus caracteres ve- 
getativos han sido publicados para regiones tropicales (Rejmánek y Brewer, 2001), un ejemplo de ellos son las contribuciones de Keller (1996) y Hargreaves (2006), siendo muy escasa aquella referida a zonas extra tropicales.

La descripción de caracteres vegetativos en las plantas vasculares en general ha sido algo descuidada por los botánicos a la hora de elaborar claves taxonómicas que permitan el reconocimiento de estas especies (Corner, 1946; Davis y Heywood, 1963). Esto resulta más evidente en la literatura referida al reconocimiento de las especies leñosas, si bien las estructuras vegetativas y macro anatómicas son más fáciles de observar que las reproductivas (Keller, 1994).

La identificación taxonómica de las especies a través de caracteres vegetativos resulta de utilidad para la realización de estudios de campo relativos a inventarios florísticos, forestales, de malezas, evaluación de pastizales, estudios de seguimientos o monitoreo de la vegetación, entre otros. La mayoría de estas publicaciones que abordan el reconocimiento de las plantas a través de sus estructuras vegetativas se refieren a las especies herbáceas (Itria, 1958, 1961; Latour, 1970; Bertiller y León, 1975; Petetin y Molinari, 1977; Frecentese, 1981; Montes et al., 2001; Degorgue y Alonso, 2013).

Si bien se han publicado numerosas contribuciones de divulgación relativas a las especies leñosas nativas de Argentina (Jozami y Muñoz, 1984; Biloni, 1990; Lahitte y Hurrell, 1999; Demaio et al., 2002, 2015, 2017; Hurrell y Lahitte, 2002; Hurrell y Bazzano, 2003; Hurrell et al., 2004; Peña-Chocarro et al., 2006; Cabral y Castro, 2007; Carosio et al., 2008) que aportan, entre otros, ilustraciones, descripciones, nombres vernáculos, distribuciones geográficas, usos, no incluyen claves dico- tómicas que posibiliten el reconocimiento de las especies. Para la provincia de Misiones se cuenta con el trabajo de Bohren et al. (2003) que permite el reconocimiento de especies forestales por características de sus cortezas, y de Kostlin (2017) para identificar algunas leguminosas leñosas utilizando caracteres vegetativos, mientras que los aportes de Miranda et al. (2000) y Giménez y Moglia (2003) utilizan caracteres dendrológicos. Las contribuciones que permiten la determinación taxonómica de las especies leñosas de la provincia de Santa Fe, correspondientes a la flora local (Ragonese y Covas, 1942; Pensiero y de la Peña, 1999; Pensiero et al., 2005; Marino et al., 2006) y regional (Burkart 1969, 1974, 1979, 1987; Burkart y Bacigalupo, 2005), se basan en forma casi exclusiva en las estructuras reproductivas. Marino et al. (2008), estudiaron la morfología de varias especies leñosas de la provincia de Santa Fe al estado de plántula y proporcionaron una clave que permite el reconocimiento de las especies en dicho estadio.

No existen actualmente trabajos que incluyan claves dicotómicas que permitan el reconocimiento de las especies leñosas nativas a través de las estructuras vegetativas de ejemplares adultos, y especialmente para aquellas que habitan en la provincia de Santa Fe. En tal sentido, el objeto de este trabajo es presentar una clave dicotómica que permita el reconocimiento de estas especies a través de sus estructuras vegetativas, aportando así una herramienta de utilidad a la hora de realizar inventarios florísticos para estudios ecológicos y planes forestales de manejo y/o conservación. 


\section{MATERIALES Y MÉTODOS}

Para la elección de los taxones tratados se tuvieron en cuenta las especies leñosas, cuyos hábitos de crecimiento correspondieran a: árboles, arbustos, palmeras y cañas, señaladas por Pensiero et al. (2005), y las mencionadas por Zuloaga et al. (2008, 2019) para la provincia de Santa Fe, excluyéndose aquellos con hábito subarbustivos y sufrútices, y algunas especies arbustivas de ocurrencia escasa o poco frecuentes.

Los caracteres vegetativos que se consideraron fueron: la corteza, presencia o ausencia de espinas o guijones, tipo de ramificación del eje o tallo principal, presencia o ausencia de látex, filotaxis de las hojas (alternas, opuestas, subopuestas, fasciculadas), tipo de hoja (simple o compuesta), características de las láminas (forma, largo, ancho, márgenes, base, ápice, color, olor), presencia o ausencia de pubescencia, pecíolos (presencia o ausencia, largo, pubescencia), entre otros. Para la terminología referida a las características de las hojas se siguió a Hickey (1974).

Para el relevamiento de los caracteres vegetativos utilizados, se tuvieron en cuenta observaciones realizadas a campo, ejemplares conservados en el herbario (SF), imágenes fotográficas, ilustraciones y las descripciones botánicas de cada taxón obtenidas de la bibliografía. Además, para cada taxón tratado se incluye la familia botánica, nombre vernáculo más común, hábito de crecimiento (arbusto, árbol, arbusto o árbol, caña, palmera), el estatus geográfico (nativa, endémica, introducida), los departamentos donde ha sido coleccionado, y un ejemplar de referencia que se conserva en el Herbario “Arturo E. Ragonese” (SF) de la Facultad de Ciencias Agrarias de la Universidad Nacional del Litoral.
La nomenclatura de los taxones y el estatus geográfico sigue a Zuloaga et al. (2019).

Se han incluido algunas especies introducidas para la flora de Argentina que con frecuencia se las observa invadiendo o habitando en distintos ambientes de la provincia.

En algunos casos, ante la dificultad de diferenciar especies afines a través de sus estructuras vegetativas, se incoluyeron como complemento caracteres de flores y/o frutos.

\section{RESULTADOS Y DISCUSIÓN}

Se presenta una clave dicotómica que permite el reconocimiento, por sus caracteres vegetativos, de 144 taxones correspondientes a 107 géneros y 46 familias, pertenecientes a la flora leñosa de la provincia de Santa Fe (Tabla 1), cuyas formas de vida corresponden a: árboles, arbustos, palmeras y cañas. Dos de los taxones tratados, Prosopis hassleri var. nigroides y Prosopis nigra var. ragonesei son endémicos de la provincia de Santa Fe.

Los taxones: Achatocarpus praecox, Aloysia gratissima var. gratissima, Broussonetia papyrifera, Byttneria filipes, Castela coccinia, Lycium cuneatum, Maclura tinctoria subsp. mora, Monteverdia spinosa, Schinus fasciculatus, Schinus longifolius, Scutia buxifolia, Solanum caavurana, Terminalia triflora, Tessaria integrifolia, Vassobia breviflora y Ximenia amaricana var. americana, poseen doble entradas en la clave debido a la variabilidad morfológica que presentan sus caracteres vegetativos. 
Flora leñosa de la provincia de Santa Fe
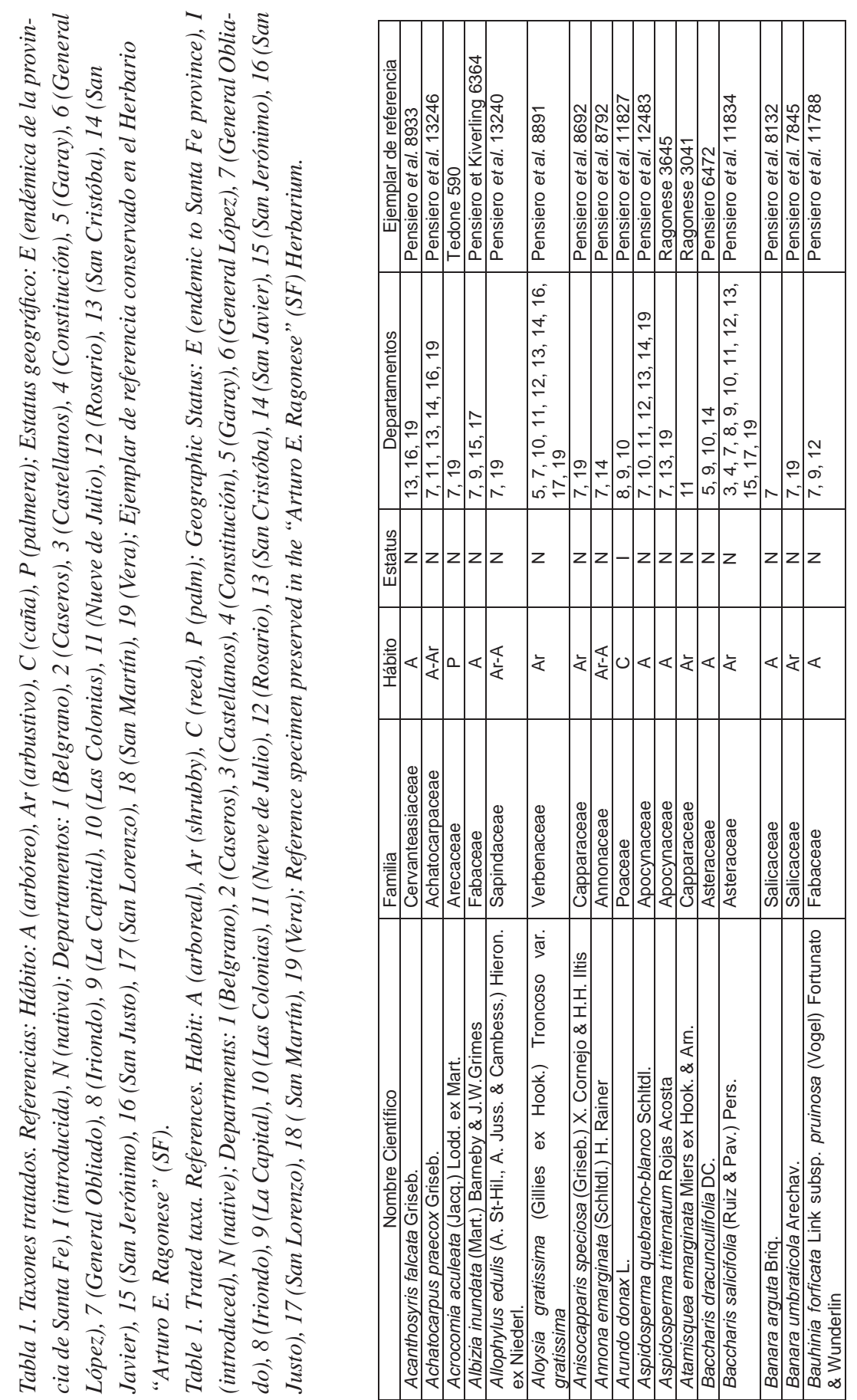

Revista FAVE - Ciencias Agrarias 20 (1) 2021 | 


\section{J. F. Pensiero}

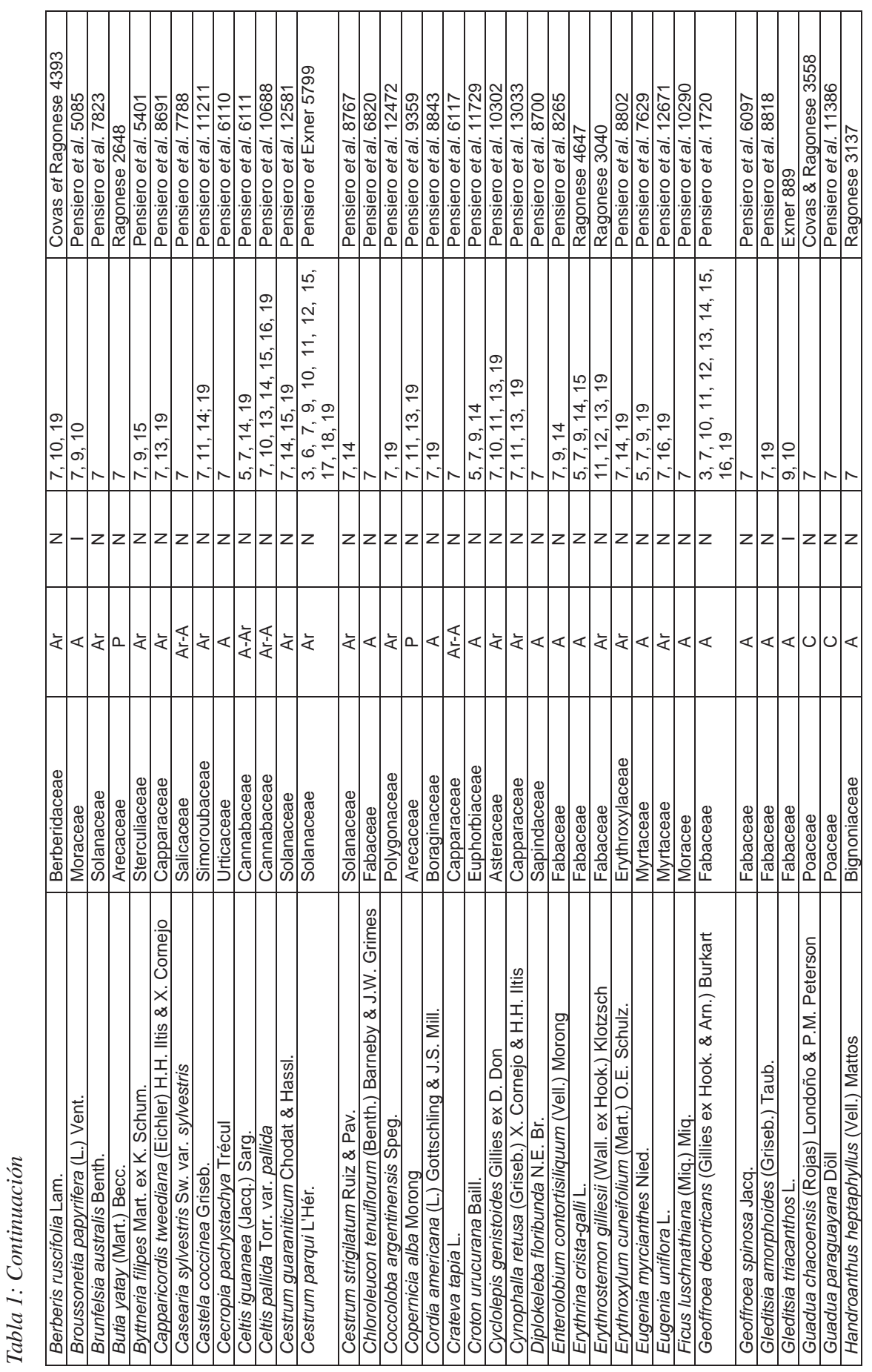


Flora leñosa de la provincia de Santa Fe

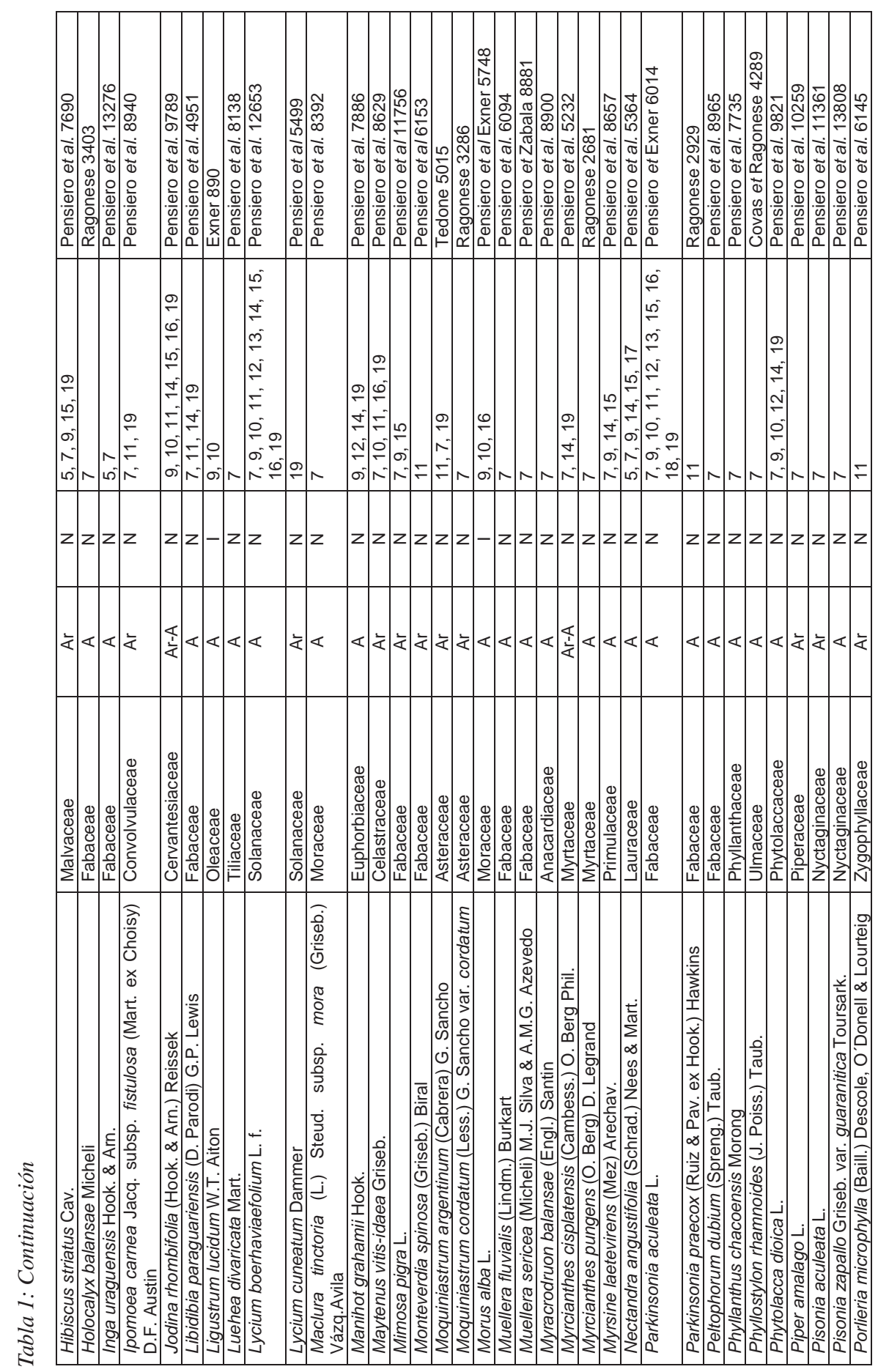

Revista FAVE - Ciencias Agrarias 20 (1) 2021 | 


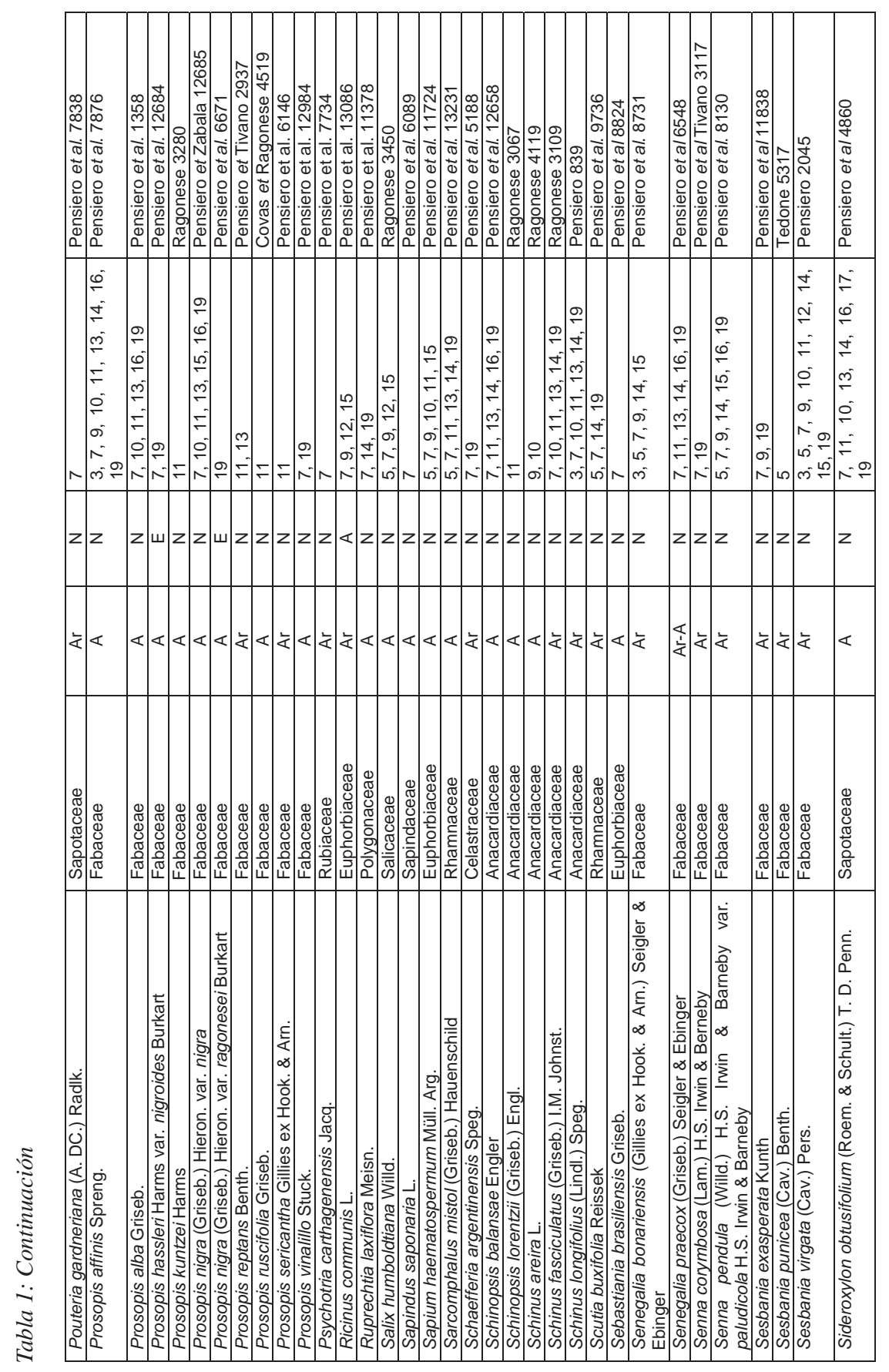


Flora leñosa de la provincia de Santa Fe

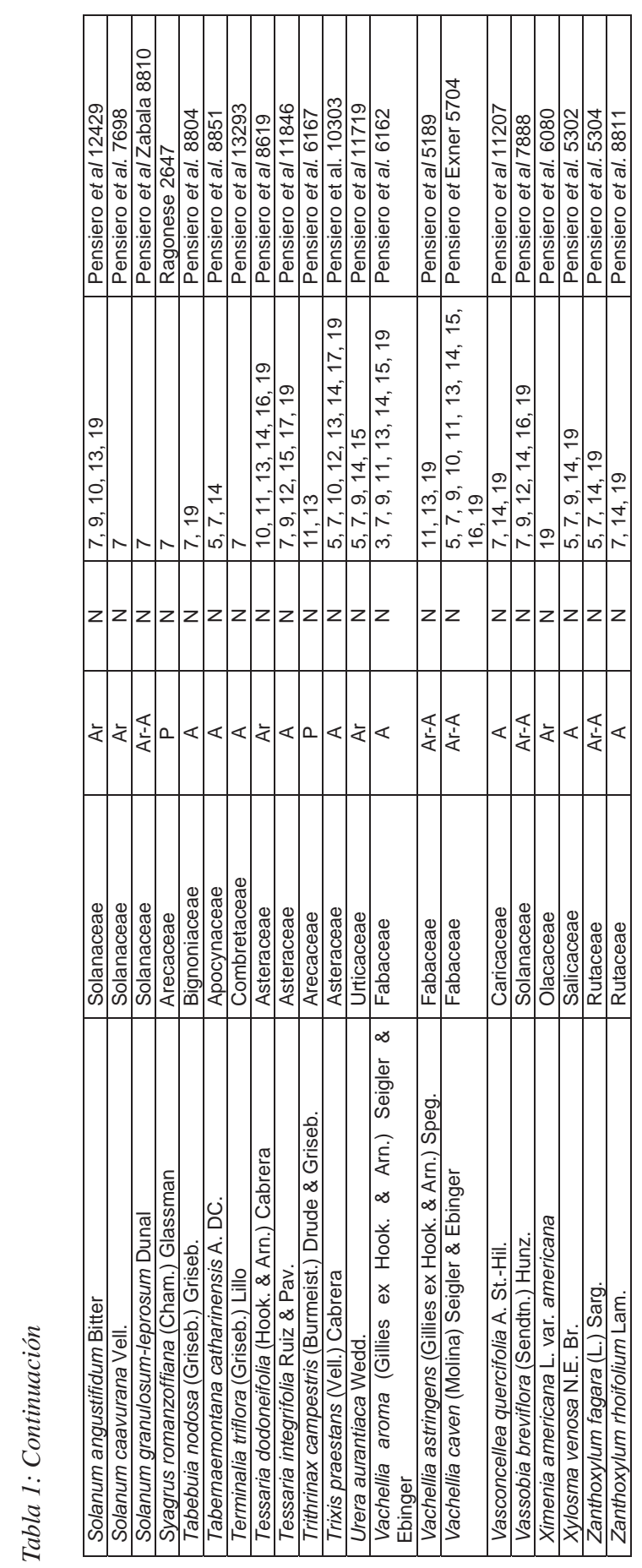

Revista FAVE - Ciencias Agrarias 20 (1) 2021 | 


\section{Clave para el reconocimiento de las especies}

1 Cañas

GRUPO 1

$1^{\prime}$ Árboles, arbustos y palmeras 2

2(1') Palmeras $\quad$ GRUPO 2

2' Árboles o arbustos 3

3(2) Árboles o arbustos subáfilos (hojas, cuando presentes, compuestas, bipinnadas, uniyugadas, muy pequeñas y tempranamente caedizas), ramosos y muy espinosos, ramas rígidas, verdes o verdes-cenicientas, terminadas en espinas

GRUPO 3

3’ Árboles o arbustos nunca subáfilos, con hojas simples o compuestas 4

4(3’) Hojas simples $\quad 5$

4' Hojas compuestas

5(4) Hojas de disposición alterna $\quad$ GRUPO 4

5' Hojas con otra disposición 6

6(5`) Hojas dispuestas en fascículos o verticilos $\quad$ GRUPO 5

6' Hojas opuestas, subopuestas o falsamente geminadas $\quad$ GRUPO 6

7(4') Fuste con espinas de 5-20 cm de largo divididas 1-3 veces $\quad$ GRUPO 7

$7^{\prime}$ Fuste sin espinas o con aguijones no mayores de $2 \mathrm{~cm}$ de largo 8

8(7') Hojas digitadas, trifolioladas o pinnado-trifolioladas $\quad$ GRUPO 8

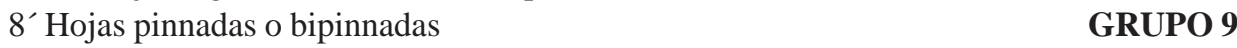

\section{GRUPO 1}

(Cañas)

1 Cañas sin espinas; hojas isomorfas, con láminas de consistencia herbáceas, bien desarrolladas, mayores que sus vainas, linear-lanceoladas, planas, de 30-60 cm de largo por 3-7 cm de ancho, cordadas en la base Arundo donax (caña de Castilla)

1' Cañas con espinas cónicas en los nudos; hojas dimorfas, las de los vástagos o ejes principales caedizas, coriáceas, formadas por una vaina bien desarrollada y una lámina triangular, 2 o 3 veces menor que su vaina, las de los ejes secundarios pseudopecioladas, lanceoladas, planas, menores de $20 \mathrm{~cm}$ de largo

2(1') Cañas huecas, al menos las principales

2' Cañas macizas

Guadua chacoensis (tacuaruzú)

Guadua paraguayana (picanilla)

\section{GRUPO 2}

(Palmeras)

1 Hojas palmadas

1' Hojas pinnadas

2(1) Pecíolos sin aguijones

2' Pecíolos provistos de fuertes aguijones retrorsos

3(1') Estípite provisto de espinas largas y rígidas

Copernicia alba (caranday)

Acrocomia aculeata (totay) 
3’ Estípite sin espinas

4(3) Pecíolo sin espinas; follaje verde lustroso

4’ Pecíolo espinoso-dentado; follaje verde glauco

Syagrus romanzoffiana (pindó)

Butia yatay (yatay)

\section{GRUPO 3}

(Árboles o arbustos subáfilos, ramosos y muy espinosos, ramas rígidas, verdes o verdes-cenicientas, terminadas en espinas)

1 Arboles; pinnas de 3-6 cm de largo, con 3-5 pares de folíólulos Prosopis kuntzei (itín)

1’Arbustos; pinnas menores de 3 m de largo, con 2-3 pares de folíólulos

Prosopis sericantha (algarrobilla)

\section{GRUPO 4}

(Árboles o arbustos, hojas simples de disposición alternas)

1 Hojas pinnatisectas o palmatisectas, con 5-13 lóbulos

1 ' Hojas enteras o lobuladas, nunca pinnatisectas o palmatisectas

2(1) Arbustos erectos o árboles; hojas palmatisectas, de 4-18 cm de largo, lóbulos mayores de $1 \mathrm{~cm}$ de ancho; pecíolo hasta $30 \mathrm{~cm}$ de largo

Manihot grahamii (mandioca brava)

2' Arbustos laxos, erectos o semitrepadores; hojas pinnatisectas, de 3-6 cm de largo, lóbulos menores de 0,5 cm de ancho; pecíolos de 0,5-1,5 cm de largo

Solanum angustifidum (jazmín)

3(1`) Hojas con láminas enteras, no lobuladas

3’ Hojas con láminas lobuladas

4(3) Hojas con láminas lineares, linear-lanceoladas o angostamente elípticas, en general menores de $1 \mathrm{~cm}$ de ancho

4’ Hojas con láminas no lineares, mayores de $1 \mathrm{~cm}$ de ancho 15

5(4) Plantas con látex Sapium haematospermum (curupí)

5’ Plantas sin látex

6(5’) Hojas con láminas lineares o estrechamente elípticas, de 0,5-3 cm de largo por 0,2$0,6 \mathrm{~cm}$ de ancho

6’ Hojas con láminas linear-lanceoladas o espatuladas, de 2-15 cm de largo por 0,5-1 cm de ancho

7(6) Arbustos con escasas hojas, ramas verde-grisáceas con estrías verde oscuras o algo azuladas; hojas grisáceas, con coloras, cubiertas de pelos malpigiáceos

Cyclolepis genistoides (palo azul)

$7^{\prime}$ Arbustos muy hojosos, ramas nunca estriadas; hojas discolores, verde oscuras en el haz y más pálidas y tomentoso-lepidotas en el envés, sin pelos malpigiáceos

8(6) Márgenes de las láminas dentados o aserrados

Atamisquea emarginata (atamisque)

8' Márgenes de las láminas enteros

9(8) Árboles de ambientes bajos, inundables

Salix humboldtiana (sauce criollo) 
9' Arbustos muy ramosos

10(9) Hojas brevemente pecioladas, pecíolos de 2-8 mm de largo, láminas marcadamente

$$
\text { 3-nervadas }
$$

Baccharis salicifolia (chilca blanca)

10` Hojas sésiles, láminas no 3-nervadas

11(10’) Hojas con láminas verde oscuras muy lustrosas, resinosas; arbustos típicos de ambientes salinos

Tessaria dodonaeifolia (chilca)

$11^{\prime}$ Hojas con láminas verde pálidas, no lustrosas ni resinosas; arbustos de ambientes variados

Baccharis dracunculifolia (chilca mata ojo)

12(8’) Hojas verdes oscuras, muy lustrosas

$12^{\prime}$ Hojas verdes o verde-glaucas, no lustrosas

Nectandra angustifolia (laurel del río)

13(12’) Hojas con láminas linear-lanceoladas, de 5-12 cm de largo, falcadas, ubicadas sobre ramas que no terminan en espinas

Acanthosyris falcata (saucillo)

13’ Hojas con láminas espatuladas, de 2-6 cm de largo, rectas, no falcadas, ubicadas sobre ramitas que terminan en punta muy aguda a modo de espina

14(13’) Hojas con láminas isomorfas o levemente dimorfas, espatuladas o linear-lanceoladas

Schinus longifolia (molle)

14` Hojas con láminas dimorfas o polimorfas, algunas espatuladas y otras ovales u obovales

Schinus fasciculatus (molle negro)

15(4`) Plantas con látex

15` Plantas sin látex

16(15) Látex rojo; hojas tornándose anaranjadas a la madurez

Croton urucurana (sangre de Drago)

16 Látex blanco; hojas no anaranjadas a la madurez

17(16') Hojas menores de $5 \mathrm{~cm}$ de largo, con las nervaduras muy ligeramente visibles

Sebastiania brasiliensis (blanquillo)

17' Hojas mayores de $5 \mathrm{~cm}$ de largo, con las nervaduras visibles particularmente en el envés

18(17) Hojas con los márgenes de las láminas notablemente aserrados

$$
\text { Maclura tinctoria subsp. mora (mora amarilla) }
$$

18` Hojas con los márgenes de las láminas enteros

19(18’) Pecíolos menores de 1 cm de largo; hojas con láminas oblongo-lanceoladas

Pouteria gardneriana (aguaí)

19` Pecíolos de 3-11 cm de largo; hojas con láminas aovadas o elípticas

20(19`) Arbustos; hojas con láminas no coriáceas ni lustrosas, aovadas, cordadas en la base, laxamente pubescentes en ambas caras, ápice agudo

Ipomoea carnea subsp. fistulosa (campanilla arbustiva)

20`Árboles; hojas con láminas algo coriáceas y lustrosas, ampliamente elípticas, glabras en ambas caras, ápice obtuso

Ficus luschnathiana (higuerón)

21(15') Hojas con pelos urticantes en el haz

Urera aurantiaca (ortiga trepadora) 
Flora leñosa de la provincia de Santa Fe

21' Hojas sin pelos urticantes 22

22(21') Hojas discoloras 23

22' Hojas concoloras o muy levemente discoloras 29

23(22) Hojas densamente pubescentes en ambas caras o a veces sólo en el envés, suaves al tacto a contrapelo 24

23' Hojas completamente glabras o bien glabras en el haz y blanco-tomentosas en el envés 25

24(23) Hojas de 2-5 cm de largo, aovadas o anchamente aovadas; pecíolo de 1-1,5 cm de largo

Capparicordis tweediana (sacha membrillo)

24' Hojas de 10-24 cm de largo, angostamente aovadas a elípticas; pecíolos de 2-6 cm de largo

25(23’) Hojas sésiles

Solanum granulosum-leprosum (fumo bravo)

Moquiniastrum cordatum var. cordatum

25' Hojas pecioladas

26(25') Pecíolos mayores de 3 cm de largo; hojas con láminas ásperas al tacto, con el ápice largamente acuminado; plantas cultivadas, introducidas

Broussonetia papyrifera (morera de papel)

26 Pecíolos menores de 1,5 cm de largo; hojas con la cara superior de las láminas suaves al tacto, con el ápice no largamente acuminado

27(26’) Plantas con espinas patentes; hojas con láminas de 2-4 cm de largo por 1-2,5 cm de ancho, glabras en ambas caras

Scutia buxifolia (coronillo)

27 Plantas sin espinas; hojas con láminas de 4-10 cm de largo por 2-6 cm de ancho, con el envés blanco-tomentoso

28(27) Láminas de consistencia coriácea, con el haz verde lustroso y los márgenes fuertemente dentado-mucronados, con solo la nervadura central bien notoria

Moquiniastrum argentinum

28` Láminas no coriáceas, con el haz verde oscuro y los márgenes finamente aserrados o dentados, con tres nervaduras centrales bien notorias

Luehea divaricata (azota caballos)

29(22`) Hojas con láminas rombiformes, con ápice punzante y ángulos laterales con espinas pequeñas, fuertemente coriáceas

Jodina rhombifolia (sombra de toro)

29`Hojas con láminas de forma variable, nunca rombiformes, con el ápice no punzante, de consistencia a veces carnosa, no coriáceas 30

30(29`) Láminas de las hojas con los márgenes enteros o muy ligeramente denticulados

30`Láminas de las hojas con los márgenes dentados o crenados en toda su extensión o en la mitad superior

31(30) Pecíolos mayores de $3 \mathrm{~cm}$ de largo

Phytolacca dioica (ombú)

31' Pecíolos menores de 2,5 cm de largo

32(31') Hojas con láminas de 9-25 cm de largo por 3-8 cm de ancho

32’ Hojas con láminas menores, de 1-9 cm de largo y menores de 4 cm de ancho 
33(32) Láminas foliares con el envés blanco-grisáceo, márgenes enteros o ligeramente denticulados

Trixis praestans (tabaco del monte)

33’ Láminas foliares con el envés verde, márgenes totalmente enteros

34

34(33’) Ramas con espinas

Vassobia breviflora (sacha perilla)

34 Ramas sin espinas

35

35(34’) Hojas con láminas notablemente palmatinervadas

Piper amalago

$35^{\prime}$ Hojas con láminas nunca palmatinervadas

36(35’) Tallos, ramas y pecíolos tomentosos, con tricomas estrellados

36 Tallos, ramas y pecíolos glabros

Cestrum strigilatum (tinta)

37(32’) Hojas con olor fétido al estrujarlas

Solanum caavurana

$37^{\prime}$ Hojas sin olor fétido al estrujarlas

Cestrum parqui (duraznillo negro)

38(37) Árboles con corteza rugosa, con resquebrajaduras más o menos profundas 39

38' Árboles o arbustos con corteza lisa, suavemente estriada o rugosa pero con resquebrajaduras poco profundas

39(38) Hojas con láminas oblongas u oblongo-lanceoladas, normalmente más largas que anchas, de 4-8 cm de largo por 1,5-2 cm de ancho, con los márgenes ondulados y ápice agudo o apiculado

Schinopsis balansae (quebracho colorado chaqueño)

39` Hojas con láminas ampliamente elípticas, no mucho más largas que anchas, de 1,5-5 cm de largo por 1,5-3,5 cm de ancho, con los márgenes no ondulados y ápice obtuso o emarginado

Phyllanthus chacoensis (balcoca)

40(37’) Hojas con láminas varias veces más larga que ancha (entre 4 y 5 veces), cubiertas con pelos blanquecinos cortos y densos en ambas caras

Tessaria integrifolia (aliso de río)

40` Hojas con láminas de no más del doble de largo que de ancho, glabras o pubescentes

41(40`) Hojas con láminas obovadas o espatuladas

41' Hojas con láminas elípticas, ampliamente elípticas, aovadas o lanceoladas

42(41) Hojas con láminas de 5-10 cm de largo por 2-3 cm de ancho, por lo general verde lustrosas, algo distanciadas entre sí

Myrsine laetevirens (canelón)

42' Hojas con láminas de 1-4 cm de largo por 1-2 cm de ancho, verdes, no lustrosas, próximas entre sí

43(42') Arbustos no espinescentes Erythroxylum cuneifolium (coca del monte)

43’ Arbustos con ramas espinescentes gruesas y rígidas

44(43) Hojas dispuestas sobre las ramificaciones espinescentes

Schinus fasciculatus (molle negro)

44' Hojas dispuestas en las axilas de las ramificaciones espinescentes, no sobre ellas

Castela coccinea (mistol del zorro)

45(41') Corteza con lenticelas (puntitos claros); hojas por lo general con manchas negras, que ennegrecen al tornarse senescentes

Achatocarpus praecox (tala negro) 
Flora leñosa de la provincia de Santa Fe

45' Cortza sin lenticelas; hojas sin manchas negras 46(45’) Hojas con láminas de consistencia carnosa 46 Hojas con láminas de consistencia no carnosa

47(46’) Hojas con láminas plegadas longitudinalmente

Maytenus vitis-idaea (carne gorda)

Ximenia americana var. americana (patai)

47 Hojas con láminas no plegadas longitudinalmente 48(47) Ápice de las láminas mucronado

Anisocapparis speciosa (sacha limón) 48` Ápice de las láminas no mucronado

49(48') Arbustos que habitan en el borde o interior de bosques húmedos, próximos a cursos de agua

49’ Árboles o arbustos generalmente heliófilos

50(49) Arbustos con ramas erectas; láminas aovadas o elípticas; flores violetas, tornándose blancas a la madurez, limbo corolino de 1,8-3 cm de diámetro

Brunfelsia australis (jazmín paraguayo)

50`Arbustos com ramas apoyanates; láminas aovadas; flores blanco-amarillentas o amarillo-verdosas, limbo corolino menor de $1 \mathrm{~cm}$ de diámetro

Cestrum guaraniticum

51(49`) Ápice de las láminas agudo

51' Ápice de las láminas obtuso o emarginado

52(51) Arbustos espinosos, apoyantes; hojas inermes o con aguijón sobre la nervadura central de la cara inferior

Byttneria filipes (abrojito)

52'Árboles o arbustos erectos, inermes; láminas inermes

53(52’) Árboles; hojas con láminas lanceoladas

53’ Arbustos erectos; hojas con láminas elípticas, ampliamente elípticas o aovadas 54

54(53’) Ramas con lenticelas; hojas con láminas de 1,5-4 cm de ancho, con los márgenes enteros, rectos y el ápice obtuso o subagudo Coccoloba argentinensis (granadillo)

54` Ramas sin lenticelas; hojas con láminas de 1-2 cm de ancho, con los márgenes algo ondulados y el ápice acuminado o agudo

Schaefferia argentinensis (árbol amarillo)

55(51’) Hojas con láminas ampliamente elípticas o redondeadas 56

55’ Hojas con láminas elípticas, aovadas o lanceoladas 58

56(55) Arbustos espinosos, ramas divaricadas; hojas glaucas o verdoso-azuladas

Lycium boerhaviaefolium (tala de burro)

56 Arbustos inermes, ramas no divaricadas; hojas verdes

57(56') Hojas glabras

Cynophalla retusa (poroto del monte)

57' Hojas cortamente pubescentes en ambas caras $\quad$ Lycium cuneatum (tala negro)

58(55’) Arbustos muy ramificados y espinosos; hojas con láminas generalmente menores de $1 \mathrm{~cm}$ de ancho

Monteverdia spinosa (abriboca) 
58’ Árboles, rara vez arbustos, no espinosos; hojas con láminas generalmente mayores de $1 \mathrm{~cm}$ de ancho

59(58’) Hojas por lo general reunidas y aproximadas entre sí hacia el ápice de las ramitas, láminas marcadamente lustrosas en la cara adaxial Cordia americana (guayaibí)

59 Hojas no reunidas y aproximadas entre sí hacia el ápice de las ramitas, láminas no marcadamente lustrosas en la cara adaxial

60(59`) Pecíolos amarillentos, mayores de 0,5 cm de largo

60` Pecíolos no amarillentos, menores de 0,5 cm de largo

Annona emarginata (chirimoya de monte) Terminalia triflora (palo amarillo)

61(30`) Ramas, especialmente las jóvenes, con espinas

61' Ramas sin espinas

62(61) Espinas de las ramas rojizas, por lo general mayores de $3 \mathrm{~cm}$ de largo

Xylosma venosa (espina colorada)

62' Espinas de las ramas no rojizas, por lo general menores de $3 \mathrm{~cm}$ de largo

63(62’) Arbustos erectos, muy ramosos; hojas con láminas de 1-2,5 cm de largo

Celtis pallida var. pallida (tala)

63’Arbustos apoyantes, trepadores; hojas con láminas de 4-8 cm de largo

64(63’) Hojas con láminas aovadas o lanceoladas, inermes o con aguijón sobre la nervadura central de la cara inferior

64` Hojas con láminas elípticas u ovado-elípticas, inermes

Byttneria filipes (abrojito)

Celtis iguanaea (tala gateador)

65(61) Follaje verde glauco, hojas con láminas cubiertas de pelos cortos y densos en ambas caras

Tessaria integrifolia (aliso de río)

65’ Follaje verde, hojas con láminas glabras en ambas caras

66(65’) Láminas elíptico-lanceoladas, al menos 3 veces más largas que anchas, con los márgenes ligeramente dentados Casearia sylvestris var. sylvestris (camboatá)

66 Láminas aovadas, no más de 2 veces de largo que su ancho, con los márgenes visiblemente dentados en toda su extensión o en su mitad superior

67(66’) Láminas de las hojas con los márgenes dentados en su mitad superior, sin glándulas en sus dientes

Phyllostylon rhamnoides (palo lanza)

67’ Láminas de las hojas con los márgenes dentados en toda su extensión, provistos de glándulas en sus dientes vistas desde la cara abaxial

68(67’) Arbustos de sotobosque; hojas con láminas lustrosas, con tres nervaduras centrales bien notorias

Banara umbraticola 
68’ Árboles heliófilos; hojas con láminas verde oscuras, por lo general no lustrosas, con solo la nervadura central bien marcada

Banara arguta (Francisco Álvarez)

69(3’) Plantas con látex

70

69` Plantas sin látex

70(69) Hojas con pecíolos de 0,5-1 cm de largo

Maclura tinctoria subsp. mora (mora amarilla)

70’ Hojas con pecíolos mayores de $10 \mathrm{~cm}$ de largo

71(70’) Hojas elíptico-lobuladas Vasconcellea quercifolia (mamón del monte)

71' Hojas palmati-lobuladas

72(71’) Hojas con láminas discoloras, con el haz verde intenso, lustroso y el envés blanquecino, ceniciento, de consistencia algo coriácea; árboles típicos de bosques en galería y albardones de arroyos y ríos del noreste de Santa Fe

Cecropia pachystachya (ambay)

72’ Hojas con láminas concoloras, de consistencia herbácea; arbustos típicos de ambientes ruderales, modificados

Ricinus communis (tártago)

73(69') Hojas bilobuladas

Bauhinia forficata subsp. pruinosa (pezuña de vaca)

73’ Hojas 3(raro 5)-lobuladas

74(73’) Hojas ásperas al tacto, discoloras, de consistencia algo coriáceas; planta cultivada, introducida

Broussonetia papyrifera (morera de papel)

74' Hojas lisas al tacto, concoloras, de consistencia membranosa 75

75(74`) Arbustos; tallos y pecíolos generalmente espinosos; cara abaxial de la lámina foliar aterciopelada; típicos de ambientes bajos, inundables

Hibiscus striatus (rosa de río)

75’ Árboles; tallos y pecíolos glabros, sin espinas; cara abaxial de la lámina foliar glabra o ligeramente pilosa; habita en sitios altos, no inundables

Morus alba (mora)

\section{GRUPO 5}

(Árboles o arbustos, hojas simples, dispuestas en fascículos o verticilos)

1 Ápice de las hojas con espina

1' Ápice de las hojas sin espina

2(1) Hojas dispuestas en fascículos, láminas con espinas en el ápice y en los márgenes; arbustos

Berberis ruscifolia (uvilla)

2’ Hojas dispuestas en verticilos trímeros, láminas con espinas sólo en el ápice; árboles o arbustos 
3(2’) Hojas con láminas elípticas a angostamente aovadas, de consistencia subcoriáceas, con 9-12 pares de nervios secundarios claramente visibles, formando un ángulo de $45^{\circ}$ respecto al nervio medio, ápice terminado en una espina de 1-2 mm de largo, débil, poco punzante Aspidosperma triternatum (quebracho lagunero)

3` Hojas con láminas angostamente elípticas, rígidas, de consistencia coriáceas, con 1230 pares de nervios secundarios poco visibles, formando ángulos muy agudos, menores de $35^{\circ}$ respecto al nervio medio, ápice terminado en una espina de 2-4 $\mathrm{mm}$ de largo, rígida y punzante Aspidosperma quebracho-blanco (quebracho blanco)

4(1) Hojas con láminas de 8-12 cm de largo y 3,5-6 cm de ancho

Vassobia breviflora (sacha perilla)

4' Hojas con láminas menores de $6 \mathrm{~cm}$ de largo y menores de $3 \mathrm{~cm}$ de ancho

5(4) Hojas con tres nervios conspicuos, bien visibles en el envés de las láminas

5 Hojas con sólo el nervio central visible

Sarcomphalus mistol (mistol)

6(5') Plantas con látex; corteza con finas estrías longitudinales de dibujo muy regular

Sideroxylon obtusifolium (guaraniná)

6 Plantas sin látex; corteza lisa o rugosa, sin finas estrías longitudinales

\section{6}

7(6') Hojas aromáticas $\quad$ Aloysia gratissima var. gratissima (cedrón del monte)

$7^{\prime}$ Hojas no aromáticas

8(7’) Plantas espinescentes

8' Plantas sin espinas, o con algunas espinas muy ralas 12

9(8) Ramificaciones espinescentes sin hojas; láminas foliares más o menos coriáceas; arbustos típicos de suelos salinos

Castela coccinea (mistol del zorro)

9’ Ramificaciones espinescentes con hojas

10(9`) Hojas con láminas plegadas longitudinalmente, elípticas u orbiculares; arbustos frecuentes en suelos salinos Ximenia americana var. americana (patai)

10` Hojas con láminas planas, no plegadas longitudinalmente; arbustos poco frecuentes en suelos salinos

11(10’) Hojas con láminas aovadas o elíptico-lanceoladas, de 0,6-2,5 cm de largo (no más largas que el doble de su ancho)

Monteverdia spinosa (abriboca)

11`Hojas con láminas espatuladas, de 2-6 cm de largo (más de tres veces de largo que su ancho)

Schinus longifolius (molle)

12(8') Corteza gruesa, con fisuras profundas de dibujo irregular; ramificaciones de a pares y en ángulo recto con la rama principal, formando cruces

Tabebuia nodosa (palo cruz) 
12' Corteza suavemente rugosa, lisa o con fisuras longitudinales y transversales superficiales; ramas con ramificación variada, no formando ángulos rectos

13(12') Corteza y ramas con lenticelas; lámina de las hojas por lo general con manchas negras, que ennegrecen al tonarse senescentes Achatocarpus praecox (tala negro)

13’ Corteza y ramas sin lenticelas; láminas de las hojas sin manchas negras

14(13’) Hojas glabras, con láminas más largas que anchas

Terminalia triflora (palo amarillo)

14 Hojas pubescentes, con láminas casi tan largas como anchas

Lycium cuneatum (tala negro)

\section{GRUPO 6}

(Árboles o arbustos, hojas simples, opuestas, subopuestas o falsamente geminadas)

1 Ramas con espinas notables

1' Ramas sin espinas

2(1) Arbustos o arbolitos, perennifolios; ramas con espinas rectas, de 2-5 cm de largo; hojas casi sésiles, pecíolos menores de 0,4 cm de largo, láminas de 2-4 cm de largo

Scutia buxifolia (coronillo)

$2^{\prime}$ Arbustos trepadores o lianas, caducifolios; ramas con espinas curvas, menores de $3 \mathrm{~cm}$ de largo; hojas con pecíolos de 0,5-3 cm de largo, láminas de 4,5-9 cm de largo

Pisonia aculeata (yaguá pindá)

3(1) Plantas con látex

Tabernaemontana catharinensis (palo víbora)

3’ Plantas sin látex

4(3’) Hojas aromáticas

4’ Hojas no aromáticas 9

5(4) Láminas de las hojas menores de $1 \mathrm{~cm}$ de ancho, algo ásperas, sin puntos translúcidos

Aloysia gratissima var. gratissima (cedrón del monte)

5’ Láminas de las hojas mayores de $1 \mathrm{~cm}$ de ancho, lisas, con puntos translúcidos 6

6(5’) Hojas pubescentes, especialmente cuando jóvenes; pecíolos de 7-10 mm de largo, pubescentes

Eugenia myrcianthes (ubajay)

6’ Hojas glabras; pecíolos de 2-10 mm de largo, glabros o pubescentes

7(6’) Ápices de las hojas punzantes; pecíolos subglabros a pubescentes

7’ Ápices de las hojas no punzantes; pecíolos glabros

Myrcianthes pungens (guaviyú)

8(7’) Ápices de las hojas acuminados u obtusos; corteza grisácea a castaño-verdosa

Eugenia uniflora (ñangapirí)

8' Ápices de las hojas agudos o brevemente apiculados; corteza por lo general de color ocre a castaño rojizo

Myrcianthes cisplatensis (guayabo colorado)

9(4`) Hojas con láminas verde-lustrosas, elípticas, de 8-20 cm de largo 
9` Hojas con láminas verdes o verde-oscuras, aovadas, aovado-oblongas u oval-lanceoladas, por lo general menores de $8 \mathrm{~cm}$ de largo

10(9) Hojas opuestas; ramas sin lenticelas

Psychotria carthagenensis (jazmín de la costa)

10` Hojas subopuestas o falsamente geminadas; ramas con lenticelas

Solanum caavurana

11(9`) Hojas con láminas oval-lanceoladas, de consistencia algo coriácea, con el haz generalmente de color verde más oscuro y lustroso $\quad$ Ligustrum lucidum (ligustro)

$11^{\prime}$ Hojas con láminas aovadas o aovado-oblongas, sin consistencia coriácea, concoloras

Pisonia zapallo var. guaranitica (zapallo caspi)

\section{GRUPO 7}

(Hojas compuestas, fuste con espinas de 5-20 cm de largo divididas 1-3 veces,)

1 Fuste y ramas maduras con espinas ramificadas irregularmente, divididas varias veces formando ramilletes

Gleditsia amorphoides (espina corona)

$1^{\prime}$ Fuste y ramas maduras con espinas divididas regularmente 1-2 veces formando ángulos rectos en relación al eje principal, con las laterales más cortas (a modo de una cruz)

Gleditsia triacanthos (acacia negra)

\section{GRUPO 8}

(Árboles o arbustos, hojas compuestas, fuste sin espinas evidentes, hojas digitadas, trifolioladas o pinnado-trifolioladas)

1 Hojas digitadas, opuestas, con 5-7 folíolos

Handroanthus heptaphyllus (lapacho rosado)

$1^{\prime}$ Hojas trifolioladas o pinnado-trifolioladas, alternas u opuestas

2(1') Ramas por lo general con espinas, hojas pinnado-trifolioladas

2` Ramas sin espinas, hojas trifolioladas

Erythrina crista-galli (seibo)

3(2') Márgenes de los folíolos lisos, enteros

Crateva tapia (naranjillo)

3’ Márgenes de los folíolos aserrados Allophylus edulis (cocú)

\section{GRUPO 9}

(Árboles o arbustos, hojas compuestas, fuste sin espinas evidentes, hojas pinnadas o bipinnadas)

1 Hojas pinnadas

1' Hojas bipinnadas

2(1) Hojas paripinnadas

2' Hojas imparipinnadas

3(2) Hojas con el raquis alado

3 ' Hojas sin el raquis alado 
4(3) Hojas con una glándula conspicua entre cada par de folíolos, folíolos algo discoloros, oscuro lustrosos en el haz y más pálidos en el envés; ramas y corteza con lenticelas

4` Hojas sin glándulas, folíolos no discoloros; ramas y corteza sin lenticelas

Inga uraguensis (ingá)

Sapindus saponaria (palo jabón)

5(3’) Hojas opuestas, folíolos de 0,5-1 cm de largo por 0,5-2 mm de ancho

Porlieria microphylla (rama crespa)

5’ Hojas alternas, folíolos de 1-7 cm de largo por 5-25 mm de ancho

6(5') Hojas con 2-8 pares de folíolos

6’ Hojas con 10-50 pares de folíolos 9

7(6) Árboles; hojas con 3-8 pares de folíolos, folíolos con los márgenes ondulados

Diplokeleba floribunda (palo piedra)

7’ Arbustos; hojas con 2-5 pares de folíolos, folíolos con los márgenes rectos, no ondulados

8(7’) Hojas con 3-5 pares de folíolos, folíolos con el ápice obtuso

Senna pendula var. paludícola (caña fístua)

8` Hojas con 2-3 pares de folíolos, folíolos con el ápice mucronado

Senna corymbosa (sen del campo)

9(6`) Árboles perennifolios, con el fuste provisto de costillas notorias; hojas con 20-30 pares de folíolos verdes lustrosos Holocalyx balansae (alecrín)

9' Arbustos caducifolios

10(9`) Hojas con 25-50 pares de folíolos Sesbania exasperata (acacia de bañado)

10` Hojas con 10-23 pares de folíolos

11(10’) Ramas ennegrecen al perder las hojas; arbustos típicos de sectores bajos, inundables; folíolos por lo general parcialmente consumidos por insectos

Sesbania virgata (rama negra)

11' Ramas no ennegrecen al perder las hojas; arbustos de albardones de las islas; folìolos enteros, no consumidos por insectos

Sesbania punicea (acacia mansa)

12(2') Fuste y ramas con corteza exfoliante

Geoffroea decorticans (chañar)

$12^{\prime}$ Fuste y ramas sin corteza exfoliante

13(12') Fuste con gruesos aguijones $\quad 14$

13' Fuste sin gruesos aguijones 15

14(13) Hojas sin aguijones Zanthoxylum fagara (tembetarí)

$14^{\prime}$ Hojas con algunos aguijones sobre la cara abaxial del pecíolo, raquis foliar y a veces sobre el nervio central de algunos folíolos Zanthoxylum rhoifolium (teta de perra)

15(13’) Folíolos por lo general mayores de $1 \mathrm{~cm}$ de ancho, y no más del doble de largo que su ancho 16

15 Folíolos menores de $1 \mathrm{~cm}$ de ancho, en general más del doble de largo que su ancho 
16(15) Hojas con 13-15 folíolos opuestos o subopuestos, con la superfície adaxial verde glauca, no lustrosa, ápice emarginado Geoffroea spinosa (maní de los indios)

16 Hojas con 4-9 folíolos marcadamente opuestos, ápice nunca emarginado

17(16`) Superficie adaxial de la hoja adpreso-pubérula, y la abaxial adpreso-serícea

Muellera sericea (ibira-ita)

17’ Superficie adaxial de la hoja glabra y lustrosa, y la abaxial opaca y pubérula

Muellera fluvialis (rabo)

18(15’) Fuste breve, robusto, tortuoso; follaje persistente, ramas marcadamente péndulas, que recuerda al sauce llorón

Schinus areira (aguaribay)

18’ Fuste bien desarrollado, recto; follaje caduco, ramas erectas o algo péndulas

19(18`) Hojas con 7-15 pares de folíolos

Schinopsis lorentzii (quebracho colorado santiagueño)

19` Hojas con 4-7 pares de folíolos Myracrodruon balansae (urunday)

20(1') Ramas, al igual que el resto de la planta, sin aguijones ni espinas 21

20’ Ramas con aguijones o espinas

21(20) Arbustos; ramas con pubescencia glandulosa, pelos rojizos, capitados

Erythrostemon gilliesii (lagaña de perro)

21'Árboles; ramas sin pubescencia glandulosa

22(21') Hojas con 8-25 pares de pinnas, pinnas con 5-30 pares de foliólulos

Peltophorum dubium (ibirá-pitá)

22` Hojas con 1-7 pares de pinnas, pinnas con 5-20 pares de foliólulos

23(22') Corteza totalmente lisa, de color verde con manchas pardo-grisáceas, exfoliante, sin lenticelas; folíólulos de 3-7 mm de largo Libidibia paraguariensis (guayacán)

23’ Corteza lisa, grisácea cenicienta u oscura, no exfoliante, con abundantes lenticelas; folíólulos de 10-40 mm de largo

24(23’) Fruto legumbre alargada, angosta, de 8-15 cm de largo por 1-1,5 cm de ancho, dehiscente; árboles de bosques ribereños e inundables

Albizia inundata (timbó blanco)

24` Fruto legumbre aplanada, curvada formando un círculo a modo de oreja o riñón, de 5-9 cm de diámetro, indehiscente; árboles de bosques altos

Enterolobium contortisiliquum (oreja de negro)

$25\left(20^{\prime}\right)$ Ramas con aguijones recurvos 26

$25^{\prime}$ Ramas con espinas, sin aguijones recurvos 28

26(25) Hojas con 2-5 pares de pinnas; arbustos o árboles; flores color crema o amarillo muy pálido

Senegalia praecox (garabato)

26’ Hojas con 5-10 pares de pinnas; arbustos, a veces apoyantes y algo trepadores; flores amarillas o rosadas 
Senegalia bonariensis (uña de gato)

28(25’) Corteza del fuste y de las ramas de color verde, lisa

28' Corteza del fuste y de las ramas pardo-negruzcas o castaño-oscuras, nunca verdes, la del fuste rugosa, corchosa o agrietadas

29(28) Hojas de 9-30 cm de largo, pinnas con folíólulos distanciados entre sí, de 0,5-1,5 mm de ancho; plantas típicas de suelos bajos, inundables, húmedos, próximo a cursos de agua

Parkinsonia aculeata (cina cina)

29’ Hojas de 2-5 cm de largo, pinnas con foliólulos próximos entre sí, de 1,5-2 mm de ancho, plantas de suelos altos, no inundables del noroeste de la provincia de Santa Fe

Parkinsonia praecox (brea)

30(28') Corteza del fuste corchosa, gruesa, con surcos longitudinales profundos formando costillas que se desprenden con facilidad; fruto legumbre espiralada, en forma de tirabuzón

Chloroleucon tenuiflorum (tatané)

30’ Corteza del fuste no corchosa y muy difícil de desprender; fruto legumbre no espiralada

31(30`) Hojas con 4-25 pares de pinnas (4-25 yugas) 32

31' Hojas con 1-3 pares de pinnas (1-3 yugas)

32(31) Raquis de la hoja de 7-15 cm de largo

Vachellia aroma (tusca)

32' Raquis de la hoja de 2-5 cm de largo

33(32') Espinas grises o blancas; hojas con 4-15 pares de pinnas

Vachellia caven (aromito)

33’ Espinas oscuras, rojizas cuando jóvenes; hojas con 4-7 pares de pinnas

Vachellia astringens (espinillo negro)

34(31́) Folíólulos por lo general mayores de 2 cm de largo y más de 0,5 cm de ancho

34 Folíólulos por lo general menores de 2 cm de largo y menores de 0,5 cm de ancho

35(34) Pinnas con 2-5 pares de folíólulos, éstos mayores de 5 cm de largo

Prosopis ruscifolia (vinal)

35’ Pinnas con 4-12 pares de folíólulos, éstos menores de 4 cm de largo

Prosopis vinalillo (vinalillo)

36(34’) Pinnas por lo general menores de $5 \mathrm{~cm}$ de largo, distancia entre foliólulos menores que el ancho de los mismos

36’ Pinnas por lo general mayores de $5 \mathrm{~cm}$ de largo (en hojas desarrolladas), distancia entre folíólulos igual o mayor que el ancho de los mismos 
37(36) Árboles; hojas con 1-3 pares de pinnas, pinnas de 1-4 cm de largo, con 10-25 pares de folíólulos de 2-8 mm de largo

Prosopis affinis (ñandubay)

37' Arbustos menores de 1,5 m de alto; hojas con 1 par de pinnas, pinnas de 0,5-1,1 cm de largo, con 5-10 pares de folí́lulos de 1,3-3,8 mm de largo

Prosopis reptans (retortuño)

38(36) Folíólulos de 5-20 mm de largo

38' Folíólulos de 2-7 mm de largo

40

39(38) Hojas con 1-3 pares de pinnas, pinnas con 25-50 pares de folíólulos; fruto legumbre pajiza-amarillenta, plana, no septada entre las semillas, por lo general recta

Prosopis alba (algarrobo blanco)

39 Hojas con 1 par de pinnas, pinnas con 6-25 pares de foliólulos; fruto legumbre con manchas violáceas, septada entre las semillas, por lo general algo curva

40(38) Folíólulos mayores de 4 mm de largo; duramen oscuro

Prosopis hassleri var. nigroides (algarrobo amarillo)

40 Folíólulos menores de 4 mm de largo; duramen amarillento

Prosopis nigra var. nigra (alarrobo negro)

Prosopis nigra var. ragonesei (algarrobo amarillo) 
Flora leñosa de la provincia de Santa Fe

\section{BIBLIOGRAFÍA}

Aizen MA, Garibaldi LA, Dondo M. 2009. Expansión de la soja y diversidad de la agricultura argentina. Ecología Austral 19:45-54.

Altieri MA, Pengue WA. 2006. La soja transgénica en América Latina. Una máquina de hambre, deforestación y devastación socioecológica. Biodiversidad 47:14-19.

Bertiller M, León RJ. 1975. Identificación, por caracteres vegetativos, de las gramíneas pertenecientes a comunidades de lugares húmedos, en la Depresión del Salado (Prov. Buenos Aires). Kurtziana 8:127-139.

Biloni JS. 1990. Árboles autóctonos argentinos. Tipografía Editora Argentina. 335 pp.

Bohren AL, Grance M, Gartland D, Miranda H, Keller, Dummel C. 2003. Clave de reconocimiento de especies forestales de Misiones, Argentina, por medio de la corteza. Yvyraretá 12:26-40.

Burkart A, Bacigalupo N. 2005. Flora Ilustrada de Entre Ríos (Argentina). Tomo VI, Parte 4. Colección Científica INTA. Buenos Aires. 627 pp.

Burkart A. 1969. Flora Ilustrada de Entre Ríos (Argentina). Tomo VI, Parte 2. Colección Científica INTA. Buenos Aires. 551 pp.

Burkart A. 1974. Flora Ilustrada de Entre Ríos (Argentina). Tomo VI, Parte 6. Colección Científica INTA. Buenos Aires. 554 pp.

Burkart A. 1979. Flora Ilustrada de Entre Ríos (Argentina). Tomo VI, Parte 5. Colección Científica INTA. Buenos Aires. 606 pp.

Burkart A. 1987. Flora Ilustrada de Entre Ríos (Argentina). Tomo VI, Parte 3. Colección Científica INTA. Buenos Aires. 763 pp.

Cabral EL, Castro M. 2007. Palmeras argentinas. Ed. L.O.L.A., Buenos Aires. 87 pp.

Carosio MC, Junqueras MJ, Andersen A, Abad SM. 2008. Árboles y arbustos nativos de la provincia de San Luis. San Luis Libro, San Luis. 137 pp.
Comer EJH. 1946. Suggestions for botanical progress. The New Phyologist 47: 185-192.

Davis PH, Heywood VH. 1963. Principles of angiosperm taxonomy. Oliver and Boyd, Edinburg hand London.556 pp.

Degorgue G, Alonso S. 2013. Gramíneas perennes nativas de las Áreas Naturales Protegidas Costero Marinas de la Estepa Patagónica, zona norte. Descripción de especies y clave para su reconocimiento por caracteres vegetativos. Fundación Patagonia Natural, Universidad Nacional de Mar del Plata. 31 pp.

Demaio P, Karlin UO, Medina M. 2002. Árboles nativos del centro de Argentina. Ed. L.O.L.A., Buenos Aires. 210 pp.

Demaio P, Karlin UO, Medina M. 2015. Árboles nativos de Argentina. Tomo 1: Centro y Cuyo. Ed. Ecoval, Córdoba. 183 pp.

Demaio P, Karlin UO, Medina M. 2017. Árboles nativos de Argentina. Tomo 2: Patagonia. Ed. Ecoval, Córdoba. 125 pp.

Frecentese MA. 1981. Identificación de las gramíneas de la provincia de La Pampa por sus caracteres vegetativos. Publicación Miscelánea. EERA INTA Anguil. 5. 40 pp.

Gasparri NI, Grau HR, Angonese JG. 2013. Linkages between soybean and neotropical deforestation: coupling and transient decoupling dynamics in a multi-decadal analysis. Global Environmental Change 23(6):16051614.

Giménez A, Moglia J. 2003. Árboles del Chaco argentino. Guía para el reconocimiento dendrológico. Santiago del Estero, Argentina. Universidad Nacional de Santiago del Estero y Secretaría de Ambiente y Desarrollo Sustentable. 306 pp.

Gori G. 1965. La Forestal: la tragedia del quebracho colorado. Ed. Platina/Stilcograf. 183 pp. 
Grau HR, Aide TM, Gasparri NI. 2005. Globalization and soybean expansion into semiarid ecosystems of Argentina. Ambio 34 (3):265.

Hargreaves P. 2006. Vegetative morphology for species identification of tropical trees: family distribution. Cerne 12:1-7.

Hickey LJ. 1974. Clasificación de la arquitectura de las hojas de Dicotiledóneas. Bol. Soc. Argent. Bot. 16:1-26.

Hurrell JA, Bazzano D, Delucchi G. 2004. Arbustos 2. Nativos y exóticos. Buenos Aires: Ed. L.O.L.A. 288 pp.

Hurrell JA, Bazzano D. 2003. Arbustos 1. Nativos y exóticos. Buenos Aires: Ed. L.O.L.A. $263 \mathrm{pp}$

Hurrell JA, Lahitte HB. 2002. Leguminosas. Nativas y exóticas. Buenos Aires: Ed. L.O.L.A. 319 pp.

Itria CD. 1958. Identificación de algunas gramíneas pampeanas por sus caracteres vegetativos. Revista Argentina de Agronomía 25 (3):81-84.

Itria CD. 1961. Identificación de las gramíneas de la provincia de La Pampa por sus caracteres vegetativos. Revista Invest. Agríc. 15 (1):5-82.

Jozami JM, Muñoz J. 1984. Árboles y Arbustos Indígenas de la Provincia de Entre Ríos. IPNAYS. Santa Fe. 421 pp.

Keller R. 1994. Neglected vegetative characters in field identification at the supraspecific level in woody plants: phyllotaxy, serial buds, syllepsis and architecture. Bot. J. Linn. Soc. 116:33-51.

Keller R. 1996. Identification of tropical woody plants in the absence of flowers and fruits. A field guide. Springer Basel AG. 248 pp.

Kostlin MR. 2017. Identificación de Leguminosae-Caesalpinoideae arbustivas-arbóreas y lianas de la Selva Paranaense (Misiones, Argentina) utilizando caracteres vegetativos. Bol. Soc. Argent. Bot. 52 (3):597-615.
Lahitte HB, Hurrell JA . 1999. Árboles Rioplatenses. Buenos Aires: Ed. L.O.L.A. 300 pp.

Latour MC. 1970. Identificación de las principales gramíneas forrajeras del Noroeste de la Patagonia por sus caracteres vegetativos. Colec. Cient. INTA. 9. Buenos Aires. 238 pp. Luna C. 2018. Alteración de los bosques nativos en el norte argentino: normativas y mecanismos de compensación por servicios ambientales. Revista de Ciencias Ambientales 52 (1):145-160.

Marino GD, Marchhetti ZY, Pensiero JF. 2006. Clave para el reconocimiento de la flora leñosa nativa del Sitio Ramsar Jaaukanigás (Provincia de Santa Fe, Argentina). Bol. Soc. Argent. Bot. 41 (1-2):77-84.

Marino GD, Mas MV, Orlandoni MJ. 2008. Morfología y reconocimiento de las principales especies leñosas nativas de la provincia de Santa Fe, Argentina, en el estado de plántula. Bol. Soc. Argent. Bot. 43:67-81.

Miranda DE, Bohren AV, Keller H, Grance LA, Gartland HM. 2000. Clave de reconocimiento de especies leñosas de Rutaceae presentes en la Selva Paranaense (Argentina), mediante el uso de caracteres dendrológicos. Quebracho 8:47-55.

Montenegro C, Gasparri I, Manghi E, Strada M, Bono J, Parmuchi G. 2004. Informe sobre deforestación en Argentina. Dirección de Bosques. Secretaría de Ambiente y Desarrollo Sustentable de la Nación. 8 pp.

Montes L, Alonso SI, Nuciari MC, Clausen AM, Guma IR, Echarte AM. 2001. Flora espontánea del sudeste bonaerense. Clave ilustrada para la identificación de las principales dicotiledóneas herbáceas por sus caracteres vegetativos. EEA Balcarce. Facultad de Ciencias Agrarias, UNMdP. 102 pp. 
Flora leñosa de la provincia de Santa Fe

Paruelo JM, Oesterheld M, Del Pino F, Guerschmann JP, Verón SR, Piñeiro Guerra G, ... Vasallo M. 2004. Patrones espaciales y temporales de la expansión de Soja en Argentina: Relación con factores socio-económicos y ambientales. Informe final LART/FAUBA al Banco Mundial. (http://www.agro.uba.ar/ users/lart/bancomundial/INFORME_final. pdf), fecha de visita 2/1/2017.

Pensiero JF, de la Peña MR. 1999. Flora y Avifauna de la provincia de Santa Fe. Talleres gráficos El Litoral Argentino. 384 pp.

Pensiero JF, Gutiérrez HF, Luchetti AM, Exner E, Kern V, Brnich E, Oakley L, Prado D, Lewis JP. 2005. Flora vascular de la provincia de Santa Fe. Claves para el reconocimiento de las familias y géneros. Catálogo sistemático de las especies. $403 \mathrm{pp}$

Peña-Chocarro M del C. de Egea Juvinel J, Vera M, Maturo H, Napp S. 2006. Guía de árboles y arbustos del Chaco húmedo. The Natural History Museum, Guyra, Paraguay, Fundación Moisés Bertoni y Fundación Hábitat y Desarrollo. Asunción, Paraguay. 291 pp.

Petetin CA, Molinari E. 1977. Clave Ilustrada para el Reconocimiento de Malezas en el Campo al Estado Vegetativo. Tomo XIV. Colección Científica INTA. Buenos Aires. 243 pp.
Ragonese AE, Covas G. 1942. Flora de la Provincia de Santa Fe (República Argentina): Las Palmeras. Darwiniana 4 (2-3):285-302.

Rejmánek M, Brewer SW. 2001. Vegetatie identification of tropical woody plants: State of the art and annotated bibliography. Biotropica 33 (2):214-228.

SAyDS. 2005. Primer Inventario Nacional de Bosques Nativos. Informe nacional. Buenos Aires.

SAyDS-UMSEF. 2007. Monitoreo de Bosque Nativo. Período 1998-2002, Período 20022006 (Datos Preliminares). Buenos Aires: SAyDS. 11 pp.

Zuloaga OF, Belgrano MJ, Zanotti CA. 2019. Actualización del catálogo de las plantas vasculares del Cono Sur. Darwiniana, nueva serie 7(2):208-278.

Zuloaga OF, Morrone O, Belgrano MJ. 2008. Catálogo de las plantas vasculares del Cono Sur (Argentina, sur de Brasil, Chile, Paraguay y Uruguay). Monogr. Syst. Bot Missouri Bot. Gard. 107. 